\title{
Midwifery Care for Mrs. K's Baby with Abdominal Bloating Using Telon Oil
}

\author{
Nofita Tri Lestari ${ }^{1}$, Diah Atmarina $Y^{2}$, Sawitri Dewi ${ }^{3}$ \\ 1,2,3 Department of Health, Universitas Muhammadiyah Purwokerto, Indonesia
}

\begin{tabular}{l} 
ARTICLE INFO \\
\hline Article history: \\
DOI: \\
$\underline{10.30595 / \text { pshms.v2i.217 }}$
\end{tabular}

Submitted:

December 6, 2021

Accepted:

January 21, 2022

Published:

January 26, 2022

Keywords:

\begin{abstract}
Bloating (meteorism, tympanities) is a symptom that indicates the presence of air or gas in the abdominal or intestinal cavity (Gina et al., 2020). In newborns (neonates) occurs because the digestive system in neonates is immature, besides that there are not enough digestive enzymes available at birth, and will only reach sufficient levels with increasing age, this is as stated by Padila et al. , 2019. To overcome flatulence in infants, nonpharmacological therapy can be used, namely by using telon oil by massaging it on the baby's stomach, this can reduce bloating in infants. To determine the application of telon oil to reduce bloating in new born. Case study report using descriptive method, the location of the residence of Mrs. K in Nangkod Village Rt02/05, Kejobong District, Purbalingga Regency. The subject of the case study was a 15-day-old newborn with flatulence. Time of case study on 9 April 2021. Data collection techniques include interviews and secondary studies including documentation and literature studies. The general condition of the new born is good, after massaging using telon oil the baby fart. Giving massage using telon oil is effective for reducing flatulence in babies.
\end{abstract}

New born, Bloating, Telon oil

This work is licensed under a Creative Commons Attribution 4.0 International License.

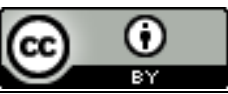

Corresponding Author:

Nofita Tri Lestari,

Department of Health, Muhammadiyah University of Purwokerto,

Soepardjo Rustam Street KM. 7, Banyumas, Indonesia

Email: nofitatrilestari@gmail.com

\section{INTRODUCTION}

Newborns (neonates) are babies who have just experienced birth and are 0-28 days. Newborns require physiological adjustments in the form of maturation, adaptation (adjusting from intrauterine life to extra uterine one), and tolerance for newborns to live well. [1]

In newborns, there are physiological changes in the functions and vital processes of the neonate, which will result in various complaints such as flatulence or abdominal bloating, crying, lethargy, or drowsiness. Bloating in newborns is a common thing because of their immature digestive systems. [2]

According to Padila et al., 2019 in Gina et al., 2020, it is explained newborns have inadequate digestive enzymes, and the enzymes will reach sufficient levels in line with the newborns' age. In addition, it is explained that bloating (meteorism, tympanitis) is a symptom that indicates the presence of air or gas in the abdominal or intestinal cavity.Midwives, as one of the health workers, have a role in neonatal services, namely providing care following the required competencies of a midwife related to the health of newborns, especially with the sixth competency, midwives provide high-quality and comprehensive care for healthy newborns to 1-month age. [3] 
Some ingredients such as telon oil can be used to treat bloating in neonates. According to research by Gina et al. (2020), the babies with a gestation period according to the inclusion criteria has been examined and given the intervention of telon oil on the baby's stomach with movements such as writing ILU (I Love You) to release the excess gas on stomach, or intervention of telon oil on the baby's stomach in a clockwise direction, which is carried out in the morning and evening to prevent bloating. Besides, it also aims to warm the body because telon oil has three oil content: coconut, eucalyptus, and fennel oil. Telon oil is a mixture of 3 kinds of oil. The word telon comes from the Javanese language, which means three. Telon oil is a blend of fennel oil, eucalyptus oil (Oleum Cajuputi), and coconut oil (Oleum Cocos). Those oils have different functions, and their benefits are in synergy. [4]

Telon oil helps prevent and treat bloating in babies and provides a warm feeling for babies. In addition, telon oil can relieve symptoms of colic heartburn in infants.

\section{RESEARCH METHOD}

This scientific paper used a case study report of a descriptive method, the location at the house of Mrs. K Nangkod Village RT 02/05 Kejobong Subdistrict, Purbalingga Regency. The subject of the case study was a newborn baby of Mrs. K, 15 days old, with abdominal bloating. The case study time was on April 9, 2021. Interviews were conducted to collect the primary data, and documentation and literature studies were implemented to collect secondary data.

\section{RESULT AND DISCUSSIONS}

In observing midwifery care for newborns with bloating, primary data collection was carried out, namely based on Mrs. K's baby aged 15 days. Subjective data were that the mother said her baby's stomach was slightly enlarged and had a sound if it was patted. Objective data obtained from patients, namely good general condition, copos mental awareness, heart rate: $143 \mathrm{x} /$ minute, breathing: $42 \mathrm{x} / \mathrm{minute}$, temperature: $36.60 C$, weight: 3400 grams, body length: $46 \mathrm{~cm}$, head circumference: $30 \mathrm{~cm}$, arm circumference: $10 \mathrm{~cm}$, chest circumference: $31 \mathrm{~cm}$, active movement and crying. On physical examination, the results were good skin turgor, reddish skin color, abdomen: enlarged, percussion: abnormal sounds, Moro reflex (yes, strong), rooting reflex (yes, strong), sucking reflex (yes, strong), grasping reflex (yes, strong), tonic neck reflex (yes, strong), swallowing reflex (yes, strong), Babinski reflex (yes, strong), and the umbilical cord was found to have detached on April 6, 2021.

Based on the data above, theory and practice fields are suitable. The case of Mrs. K's baby did not find any emergency. Then no immediate treatment was carried out. Thus, both theory and practice fields showed appropriateness.

\section{CONSLUSION}

Based on the discussion about the management of Mrs. K's baby case (neonates with bloating) in Nangkod village RT 02/05 Kejobong Subdistrict, Purbalingga Regency using midwifery management according to Varney with the SOAP documentation method, the authors conclude the following:

From the study conducted by the author, the subjective data obtained that the stomach of Mrs. K's baby is slightly enlarged, and the mother felt anxious. Moreover, the objective data showed general awareness: good, consciousness: compos mentis, heart rate: $143 \mathrm{x} /$ minute, breathing: $42 \mathrm{x} /$ minute, temperature: $36.60 \mathrm{C}$, weight: 3400 grams, body length: $46 \mathrm{~cm}$, head circumference: $30 \mathrm{~cm}$, arm circumference: $10 \mathrm{~cm}$, chest circumference: $31 \mathrm{~cm}$, active movement and crying. On physical examination, the results were good skin turgor, reddish skin color, abdomen: enlarged, percussion: abnormal sound, Moro reflex (yes, strong), rooting reflex (yes, strong), sucking reflex (yes, strong), reflex grasping (yes, strong), tonic neck reflex (yes, strong), swallowing reflex (yes, strong), Babinski reflex (yes, strong), and the umbilical cord was found to have detached on April 6, 2021.

From the subjective and objective data mentioned above, it can be diagnosed that the baby of Mrs. $\mathrm{K}, 15$ days old, experienced abdominal bloating. For the management of the diagnosis, some actions were carried out, namely explaining the results of the examinations, informing Mrs. K about the examination results, and explaining the current situation, encouraging the mother not to worry about the current state of her baby. In addition, it was recommended for the mother to massage the baby using telon oil to reduce bloating while practicing massage movements on babies directly. For the evaluation/results of the management, the results showed that the mother understood her baby's condition now, and she was willing to massage her baby using telon oil to reduce bloating. Furthermore, the mother could also practice the massage movements properly.

\section{Acknowledgements}

Thank you to Allah SWT, both parents and all comrades in arms who have helped from beginning to end. 


\section{REFERENCES}

[1] Marmi dan Kukuh Rahardjo, “Asuhan Neonatus Bayi Balita Dan Anak Prasekolah,” Yogyakarta: Pustaka Pelajar, 2012.

[2] Permatasari, G., Pramesti, N. H., \& Nurhayati, S. M, "Pemberian Minyak Telon Dalam Upaya Mencegah Perut Kembung Pada Bayi Baru Lahir,” Journal of Telenursing (JOTING), 2(1), 102, 2020. https://doi.org/10.31539/joting.v2i1.1095

[3] S. L. A. Ningsih, S. Widanti \& S. Sawandi,"Peran Bidan Dalam Pelaksanaan Permenkes Nomor 53 Tahun 2014 Tentang Pelayanan Kesehatan Neonatal Pada Bayi Baru Lahir Di Puskesmas Kaleroang Sulawesi Tengah," Jurnal Hukum Kesehatan (SOEPRA), 4(1), 76, 2018. http://journal.unika.ac.id/index.php/shk

[4] F. H. P .Solarbesain, I. Pudjihastuti, "Pengaruh Komposisi Pada Minyak Telon Terhadap Uji Indeks Bias Dengan Menggunakan Refraktometer Tipe Way Abbe," Metana Media Komunikasi Rekayasa Proses dan Teknologi Tepat Guna, 15(1), 32-36. https://DOI: 10.14710/metana.v15i1.20330, 2019.

[5] G. N. F. Sari, E. S. Rejeki, M. P. Rahayu, N. Harmastuti, T. Turahman, \& Supriyadi, "Pelatihan Pembuatan Minyak Telon Antinyamuk Sebagai Upaya Perawatan Kesehatan Anak Dan Perintisan Home Industri Di Surakarta," Journal of Dedicators Community, 5(1), 59-65, 2021. https://DOI:10.34001/JDC.V5i1.1192 